Skoroplyas Iryna. Cuttings Roses on Different Substrate in Kremenets Botanical Garden. The results of micropagation rose promising for use in decorative and industrial nursery. We consider the effect of growth regulators on the basis of pyridine derivatives on the rooting of green cuttings roses of the accelerated receipt of planting material. Found that the use of growth promoters of the Kornevin yields better results than the Epinomu and Heteroauksun and the control of reproduction in the green roses from cuttings. Results showed the highest grade «Wartburg», and the lowest - «Vohni majaka». It should also be noted that the process took root quickly in all grades in the substrate peat + sand + leaf soil and in the treated cuttings «Kornevinom» rooting process went faster and were more rooted cuttings.

Key words: cloning, green cuttings, rose, substratum.

Стаття надійшла до редколегії 20.01.2016 p.

УДК 502:581.9(477)

Анна Савоськіна

\title{
Біоморфологічна та екологічна структура екзотичної дендросозофлори штучних заповідних парків Українського Полісся
}

У статті наведено результати аналізу біоморфологічної та екологічної структури раритетної екзотичної дендрофлори ex situ заповідних парків Українського Полісся. Виявлено, що в складі заповідної дендроекзосозофлори цього регіону переважаючою є група дерев. За відношенням до екоумов домінують геліофіти, мезофіти та мезотрофи.

Ключові слова: Українське Полісся, заповідні парки, дендросозоекзоти, структура дендроекзосозофлори, біоморфи, екогрупи.

Постановка наукової проблеми та їі значення. Для росту й розвитку значної частки екзотичних деревних рослин в Українському Поліссі сприятливими є екоумови рівнинного рельєфу із широкими заболоченими річковими долинами, позитивним балансом вологи, переважанням дерново-підзолистих і болотних грунтів та високим рівнем грунтових вод. Значна зволоженість зумовила розвиток підзолистого й болотного процесів грунтоутворення та формування лучної, болотної й лісової рослинності. Клімат Українського Полісся помірно континентальний із теплим і вологим літом і м’якою хмарною зимою [1] також сприяв еволюційному формуванню протягом кайнозойської ери автохтонної, а в останні кілька століть - й екзотичної дендрофлори, зокрема видів деревних рослин різних типів життєвих форм $[1,2]$. Тобто значно менш тривалим є процес адаптації й антропогенної еволюції дендроекзотів в досліджуваному регіоні, який забезпечують, передусім, штучні заповідні парки. У цьому аспекті важливим і першочерговим завданням дендросозології $\epsilon$ комплексні дослідження власне раритетної компоненти екзотичної дендрофлори заповідних парків Українського Полісся. На основі таких досліджень потрібно розробити прикладні основи збереження, відтворення, збагачення й збалансованого використання дендросозоекзотів в антропогенізованому середовищі Українського Полісся.

Мета наших досліджень - аналіз біоморфологічної та екологічної структури дендроекзосозофлори штучних заповідних парків Українського Полісся. Для досягнення мети потрібно було здійснити інвентаризацію видів дендроекзосозофлори. Для цього науковими полігонами інвентаризаційних досліджень були Ботанічний сад Житомирського національного агроекологічного університету, Менський зоологічний парк (Чернігівська область), дендрологічні парки - Березнівський (Рівненська область), Еліта, Гладковицький та Пілява (усі три - у Житомирській області) та 47 парківпам'яток садово-паркового мистецтва, які розміщені в межах різних адміністративних і фізикогеографічних областей усього Українського Полісся.

Аналіз досліджень цієї проблеми. Наукові дослідження автохтонних раритетних видів рослин на території Українського Полісся за різними напрямами вчені розпочали досить давно, десь у межах

(C) Савоськіна А., 2016 
останнього сторіччя. Сучасний період таких досліджень на території окремих адміністративних областей і регіону в цілому пов'язаний з іменами I. М. Григори, Т. Л. Андрієнко, О. І. Прядко, С. Ю. Поповича, О. О. Орлова, В. Т. Харчишина, Ю. О. Карпенка, О. В. Лукаша, С. О. Потоцької та ін.

Значно менше флористичних досліджень в Україні в цілому розглядають раритетні види екзотичних деревних рослин. У цьому аспекті під керівництвом С. Ю. Поповича групою молодих дослідників започатковано й здійснено комплексний аналіз раритетної компоненти дендрофлори, як природних, так і штучних об'єктів природно-заповідного фонду Лісостепу та Степу України [6, 7].

Наші дослідження на Українському Поліссі проводяться власне в руслі цього дендросозологічного напряму $[8,9]$. Для аналізу біоморфологічної структури дендроекзосозофлори штучних заповідних парків Українського Полісся ми використали класифікації життєвих форм Х. Раункієра та I. Г. Серебрякова [5]. Зокрема, Х. Раункієр, залежно від положення бруньок відновлення в рослин щодо поверхні грунту, їх фізіономічні реакції й сезонні зміни, виділив такі основні біологічні типи: фанерофіти, хамефіти, гемікриптофіти, криптофіти, терофіти, які, зі свого боку, можуть поділятися на менші за рангом групи.

Виклад основного матеріалу й обгрунтування отриманих результатів дослідження. Наш біоморфологічний аналіз за Х. Раункієром показав, що серед дослідженої дендроекзосозофлори виявлено один біологічний тип - це фанерофіти та чотири його групи, а саме (рис. 1): мегафанерофіти: а) зимовозелені дерева - 26 видів (26,3\%); б) листопадні дерева - 12 видів (12,1 \%); мезофанерофіти: а) зимовозелені дерева - 22 види (22,2 \%); в) листопадні дерева - 24 види (24,2 \%); мікрофанерофіти: а) зимовозелені дерева / чагарники - два види $(2,0 \%)$; б) листопадні дерева - сім видів (7,0\%); нанофанерофіти: а) зимозелені чагарники - три види $(3,0 \%)$; листопадні чагарники - три види $(3,0 \%)$.

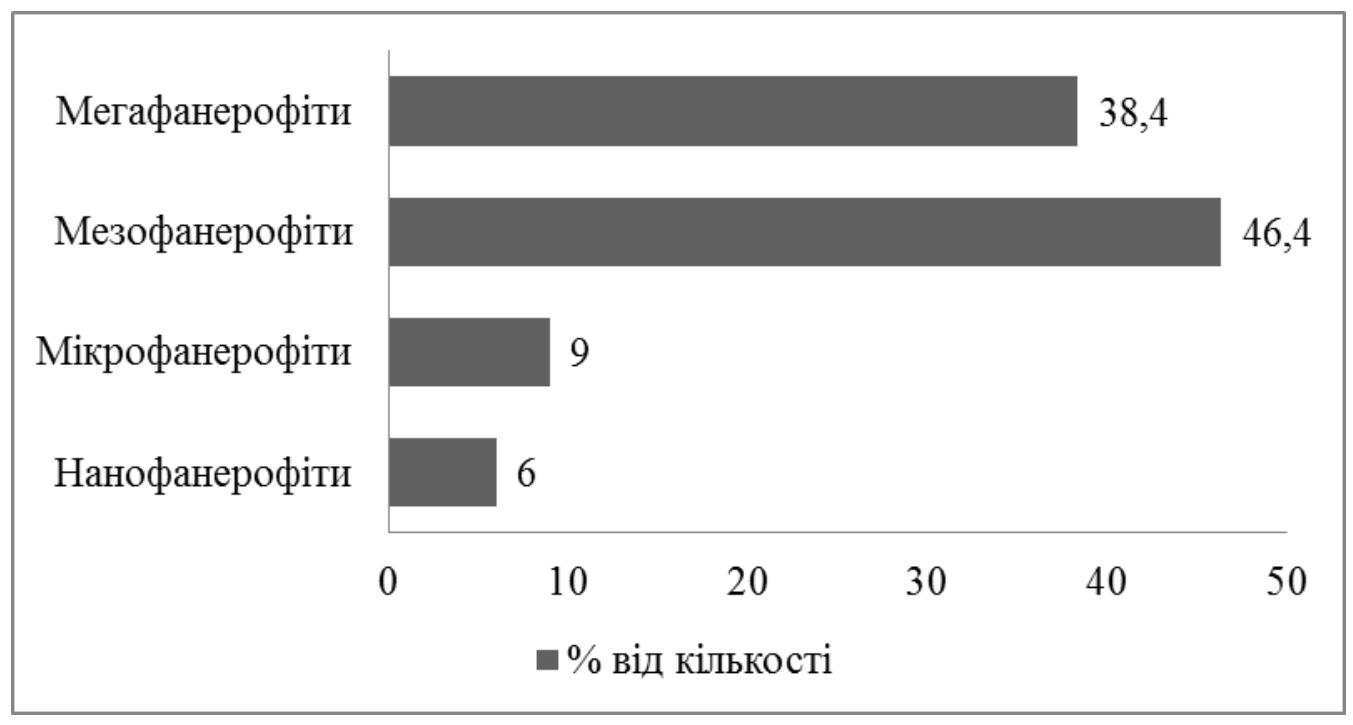

Рис. 1. Кількісне співвідношення видів біоморфогруп дендросозофлори штучних заповідних парків Украӥнського Полісся

За класифікацією I. Г. Серебрякова [4] серед видів дендроекзосозофлори штучних заповідних парків Українського Полісся виявлено представників трьох типів життєвих форм - дерева, чагарники та деревні ліани (рис. 2).

Переважаючою є група дерев - 90 видів (91,0 \%), із яких вічнозелених - 47 (47,4 \%) видів (Chamaecyparis pisifera Sieb. et Zucc., Pinus banksiana Lamb., Pinus strobus L., Pinus uncinata Ramond ex DC, Pinus monticola Dougl. ex D. Don, Pinus rigida Mill, Pinus koraiensis Sieb. et Zucc., Picea rubens Sarg., Picea mariana Britt., Picea asperata Mast., Abies balsamea (L.) Mill. та ін.), а листопадних - 43 (42,6 \%) види (Ginkgo biloba L., Larix laricina Koch, Larix decidua Mill., Larix sibirica Ledeb., Armeniaca vulgaris Mill., Cercidiphyllum japonicum Sieb. et Zucc., Betula ermanii Cham., Betula lenta L., Betula maximowicziana Regel, Betula nigra L., Eucommia ulmoides Oliv., Malus niedzwetzkyana Dieck, Malus sieversii (Ledeb.) M. Roem. й ін. ). 


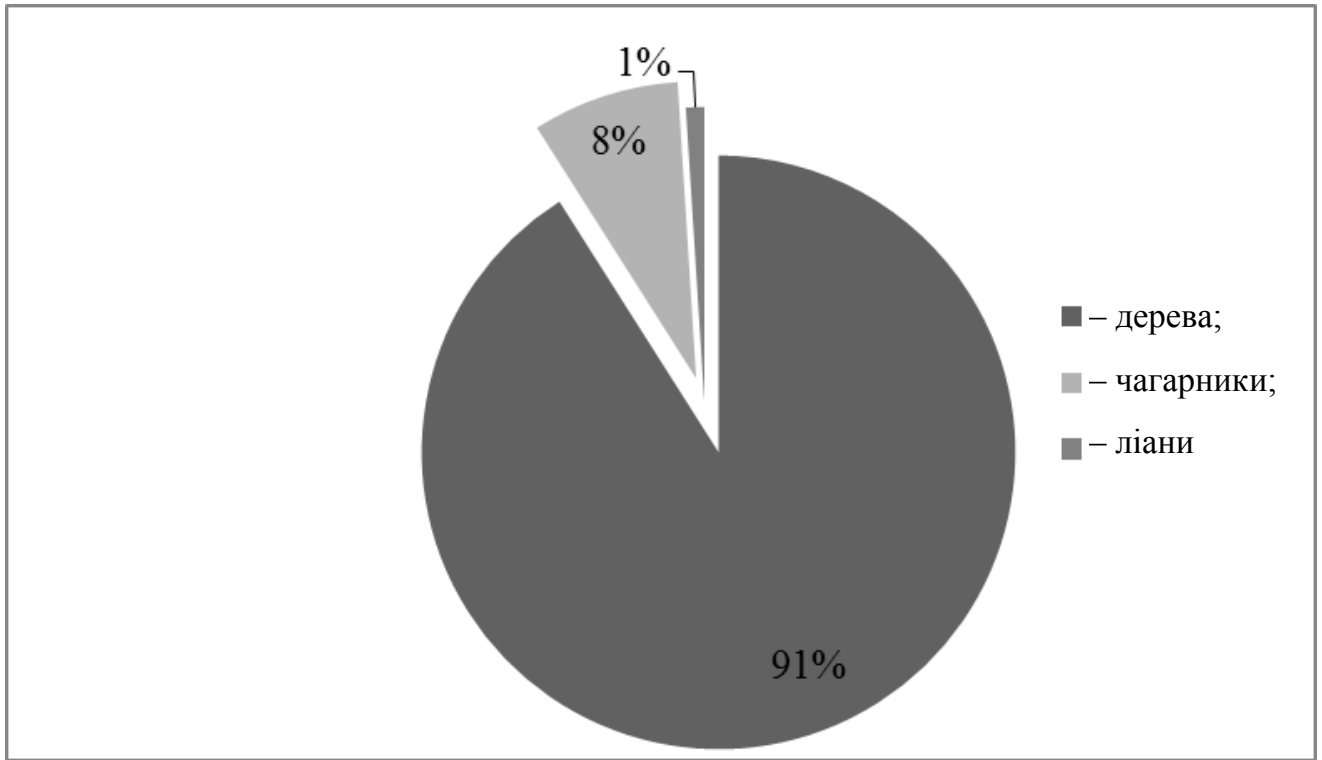

Рис. 2. Кількісний біоморфологічних спектр розподілу видів дендросозофлори штучних заповідних парків Українського Полісся

До групи чагарників належить вісім видів (8,0\%), серед яких листопадних - чотири $(4,0 \%)$, (Amorpha californica Nutt. ex Torr. \& A. Gray, Betula occidentalis Hook., Betula oycoviensis Besser, Prunus cocomilia Ten) і вічнозелених - чотири (4,0 \%), (Microbiota decussata Kom., Juniperus chinensis L. var. sargentii A. Henry). Один вид (1,0\%) належить до деревоподібних ліан (Vitis vinifera L.). Також потрібно відзначити, що деякі види (Microbiota decussata Kom., Betula occidentalis Hook., Betula oycoviensis Besser, Prunus cocomilia Ten) водночас можуть бути віднесені як до групи дерев, так і до групи чагарників.

Оскільки переважаючим типом життєвої форми дендроекзосозофлори штучних заповідних парків Українського Полісся є дерева, під час проведення досліджень проаналізовано їх за класами висоти (рис. 3). При цьому виділено чотири групи дерев за висотою: дерева першої величини -

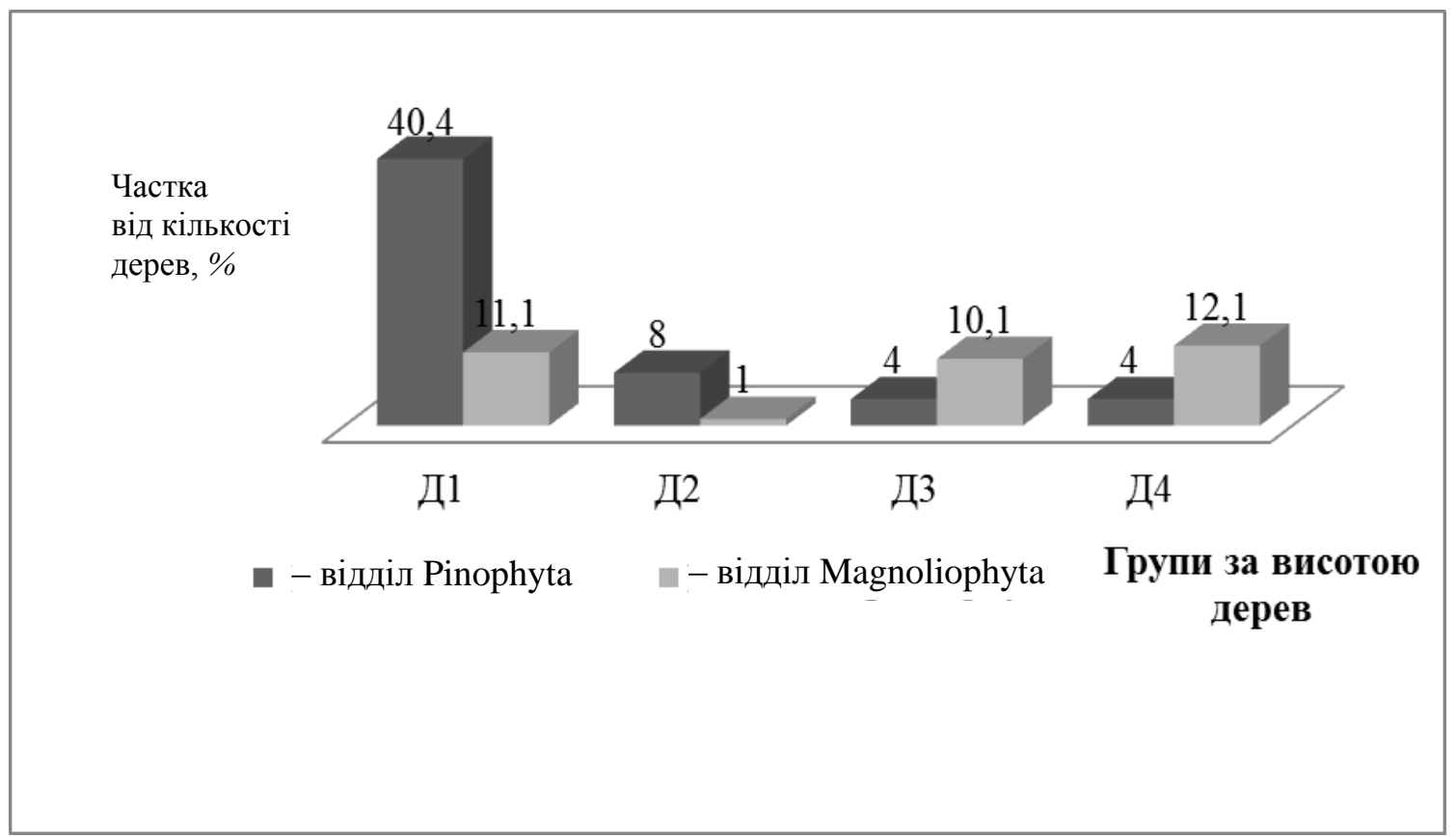

Рис. 3. Диференцііація раритетних видів екзотичних дерев ех situ за їх висотою: Д - дерева першої величини; $Д_{2}$ - дерева другої величини; Д 
висотою понад 25 м, другої - 20-25 м, третьої - 15-20 м, четвертої величини - 5 (7)-15 м. Диференціація чагарників за трьома групами така: найвищі (2,5-5 м), середні (1-2,5 м) і низькі (0,5-1 м) [5]. До дерев першої величини віднесено 51 (50,5 \%) досліджений вид.

Більшість видів (40, 40,4 \%) дерев першої величини належить до відділу Pinophyta, a caмe: Ginkgo biloba L., Chamaecyparis lausoniana (Andr.) Parl., Metasequoia glyptostroboides Hu et Cheng, Larix gmelini (Rupr.) Rupr., Picea glauca (Moench.) Voss., Picea asperata Mast., Picea schrenkiana Fisch. та ін. Відділ Magnoliophyta представлений 11 (11,1 \%) видами (Betula maximowicziana Regel, Betula papyrifera Marshall, Betula costata Trautv., Betula nigra L., Aesculus hippocastanum L., Juglans regia L., Pterocarya pterocarpa (Michx.) Kunth та ін.).

Серед раритетних екзотичних видів чагарників за їх висотою виявлено всі три групи. До відділу Pinophyta по одному виду належить до групи найвищих (Juniperus pseudosabina F. et M.) i середніх (Juniperus chinensis L. var. sargentii A. Henry). До групи низьких віднесено два види (Microbiota decussata Kom., Juniperus procumbens Sieb.).

Серед представників відділу Magnoliophyta виявлено чотири (4,0 \%) види (Amorpha californica Nutt. ex Torr. \& A. Gray, Betula ovalifolia Rupr., Sibiraea altaensis (Laxm.) Schneid., Forsythia europaea Degen et Bald.), які, зі свого боку, належать до групи середніх за висотою чагарників.

Екологічний аналіз заповідної дендроекзосозофлори Українського Полісся проводився за критерієм відношення рослин до найбільш необхідних екофакторів (кліматичних й едафічних), зокрема води, світла, температури та родючості грунту (табл. 1).

Таблиия 1

Екологічна структура дослідженої дендросозофлори

\begin{tabular}{|c|c|c|c|}
\hline Екофактор & Екогрупа & $\begin{array}{c}\text { Кількість } \\
\text { видів } \\
\end{array}$ & $\begin{array}{c}\text { Частка від загальної } \\
\text { кількості видів, \% }\end{array}$ \\
\hline \multirow{3}{*}{ Світло } & скіофіти & 35 & 35,3 \\
\hline & геліофіти & 43 & 43,4 \\
\hline & геміскіофіти & 17 & 17,1 \\
\hline \multirow{7}{*}{ Волога } & гігрофіти & 29 & 29,2 \\
\hline & гігромезофіти & 2 & 2,0 \\
\hline & мезогігрофіти & 1 & 1,0 \\
\hline & мезофіти & 41 & 41,7 \\
\hline & мезоксерофіти & 1 & 1,0 \\
\hline & ксеромезофіти & 6 & 6,0 \\
\hline & ксерофіти & 17 & 17,1 \\
\hline \multirow{4}{*}{ Трофність } & евтрофи & 21 & 21,2 \\
\hline & мезотрофи & 43 & 43,4 \\
\hline & мезооліготрофи & 4 & 4,0 \\
\hline & оліготрофи & 21 & 21,2 \\
\hline \multirow{4}{*}{ Температура } & дуже морозостійкі & 5 & 5,0 \\
\hline & морозостійкі & 72 & 72,7 \\
\hline & відносно морозостійкі & 18 & 18,1 \\
\hline & неморозостійкі & 5 & 5,0 \\
\hline
\end{tabular}

Під час дослідження екологічної структури заповідної дендроекзосозофлори Українського Полісся залежно від вимогливості рослин до умов зволоження виявлено три основні групи: ксерофіти, мезофіти й гігрофіти. Більшість видів, які ростуть у штучних об'єктах природно-заповідного фонду Українського Полісся, належать до групи мезофітів - 41,7 \%. Ксерофіти складають 17,1 \%, а гігрофіти - 29,2 \%. Решта видів належить до перехідних форм, які більшою чи меншою мірою потребують вологи.

Видовий склад заповідної екзотичної дендросозофлори Українського Полісся включає такі типи гігроморф: гігрофіти - Chamaecyparis pisifera Sieb. et Zucc., Chamaecyparis thyoides B. S. P., Metasequoia glyptostroboides Hu et Cheng та ін.; гігромезофіти - Pinus rigida Mill, Picea rubens Sarg.; мезогігрофіт - Alnus japonica (Thunb.) Steud; мезофіти - Ginkgo biloba L., Chamaecyparis lausoniana (Andr.) Parl., Microbiota decussata Kom., Larix sibirica Ledeb. й ін.; мезоксерофіти - Armeniaca vulgaris 
Mill.; ксеромезофіти - Betula papyrifera Marshall, Betula raddeana Trautv., Betula schugnaninica (B. Fedtsch.) Litv., Quercus dentata Thunb., Prunus cocomilia Ten; ксерофіти - Pseudotsuga menziesii (Mird.) Franco, Pinus uncinata Ramond ex DC та ін.

За відношенням до світла досліджені раритетні види деревних рослин розподілено на три групи: світлолюбні (геліофіти), напівтіневитривалі (геміскіофіти) і тіневитривалі (скіофіти). Найчисельнішою виявилася група геліофітів - 43 (43,4 \%) види (Larix decidua Mill., Pinus banksiana Lamb., Platycladus orientalis (L.) Franko., Quercus dentata Thunb., Forsythia europaea Degen et Bald., Cercis chinensis Bunge, Malus sieversii (Ledeb.) М. Roem. й ін.). Найменш вимогливі (скіофіти) складають 35,3\% (Thuja occidentalis L., Picea pungens Engelm.). Зі свого боку, до групи геміскіофітів входять 17 (17,1 \%) видів (Larix kaempferi (Lambert) Carr., Betula ermanii Cham., Eucommia ulmoides Oliv., Pterocarya pterocarpa (Michx.) Kunth та ін.).

Як відомо, одним із головних факторів розподілу рослин на земній поверхні є тепло. Основним показником успішного росту рослин у нових умовах інтродукції є зимостійкість - властивість організмів витримувати низьку температуру повітря протягом тривалого періоду. Вона залежить від багатьох екзогенних й ендогенних чинників і характеризується низкою ознак. У нашому дослідженні до зимостійких рослин (0-I бал) належить основна частка, тобто 90 видів $(89,1 \%)$. Представники Циркумбореальної та північно-західної частини Атлантично-Північноамериканської флористичних областей $є$ найбільш зимостійкими видами й характеризуються широкою амплітудою морозостійкості. До них належать Picea pungens Engelm., Picea glauca (Moench) Voss, Larix gmelini, Larix kaempferi, Microbiota decussata, Pseudotsuga menziesii, Pinus strobus, Pinus banksiana, Pinus sibirica, Pinus koraiensis Siebold \& Zucc., Abies concolor (Gordon) Lindl. ex Hildebr. та ін. Обмерзання не більше 50 \% однорічних пагонів спостерігається в таких видів: Pinus wallichiana A. B. Jacks., Chamaecyparis lausoniana (Andr.) Parl. і деяких ін. Менш зимостійкі види походять із Середземноморської та південної частини Атлантично-Північноамериканської й інших флористичних областей (Platycladus orientalis (L.) Franko., Armeniaca vulgaris Mill., Juglans regia L.). Незначною кількістю в раритетній дендроекзофлорі дослідженого регіону представлені недостатньо зимостійкі рослини - Cercis chinensis Bunge, Cercis canadensis L. та деякі інші.

Здатність рослин витримувати найнижчі мінімуми температур (нижче $0^{\circ} \mathrm{C}$ ) називають морозостійкістю, яка зумовлюється біологічними, анатомо-морфологічними й фізіологічними властивостями рослин, залежить від стадії розвитку та умов місцезростання рослин. Зокрема, у старшому віці рослини більш морозостійкі, що, зі свого боку, може пояснювати присутність вікових деревних екзотів на території Українського Полісся. За ступенем морозостійкості раритетні види деревних рослин поділяються на п'ять груп: 1 - дуже морозостійкі; 2 - морозостійкі; 3 - відносно морозостійкі; 4 - неморозостійкі; 5 - теплолюбні [6]. Аналізуючи морозостійкість видів раритетної екзотичної дендрофлори штучних об'єктів природно-заповідного фонду, виявлено, що переважає група морозостійких видів, які здатні витримувати морози $-25-35^{\circ} \mathrm{C}$. Їх кількість складає 72 види (72,7 \%), зокрема Tsuga canadensis, Picea orientalis, Abies nordmanniana, Thuja occidentalis L., Pinus banksiana Lamb.). До групи досить морозостійких деревних рослин, які переносять температури нижче $-35^{\circ} \mathrm{C}$, належать види Larix sibirica Ledeb., Larix gmelini, Taxus cuspidata, Abies balsamea, Aralia chinensis та ін. По кілька видів входить до груп відносно морозостійких, неморозостійких деревних рослин (Platanus orientalis L.) та теплолюбних (Liriodendron tulipifera L.).

За вимогливістю до валового вмісту поживних речовин у грунті рослини поділяють на такі три екогрупи: евтрофні, мезотрофні й оліготрофні. Серед досліджених видів рослин Українського Полісся переважають мезотрофи - рослин середньої вимогливості до родючості грунту, які можуть рости на порівняно бідних гумусом супісках і підзолистих грунтах. До цієї групи віднесено 43 види (43,4 \%), a саме: Ginkgo biloba L., Metasequoia glyptostroboides Hu et Cheng, Microbiota decussata Kom., Larix laricina Koch, L. kaempferi (Lambert) Carr., Armeniaca vulgaris Mill., Aralia chinensis Rehd., Cercidiphyllum japonicum Sieb. et Zucc., Betula ermanii Cham., B. lenta L., Betula kirghisorum Sav.Ryczg., Sibiraea altaensis (Laxm.) Schneid. та ін. Майже однакова кількість видів належить до решти груп. Зокрема, групу евтрофів (мегатрофів), до якої належать деревні види, які нормально розвиваються лише на багатих мінеральними речовинами й гумусом грунтах, складає $21(21,2 \%)$ вид (Chamaecyparis pisifera Sieb. et Zucc., Pinus koraiensis Sieb. et Zucc., Thuja plicata D. Don, Abies holophylla Maxim., Juglans regia L., Carpinus cordata Blume). До групи оліготрофів теж належить 
21 вид (21,2 \%), зокрема Chamaecyparis lausoniana (Andr.) Parl., Larix gmelini (Rupr.) Rupr., Larix sibirica Ledeb., Pinus banksiana Lamb., Platycladus orientalis (L.) Franko, Picea engelmannii Engelm., Picea glauca (Moench.) Voss., Juniperus virginiana L., Betula populifolia Marsh., Robinia pseudoacacia L., Prunus cocomilia Ten, Cercis canadensis L. та інші. Перехідну групу мезооліготрофів склали чотири види: Pinus monticola Dougl. ex D. Don, Pinus ponderosa Dougl, Picea orientalis (L.) Link., Cercis chinensis Bunge.

Також треба зазначити, що серед заповідних раритетів культивованої дендрофлори Українського Полісся є рослини, яким притаманні специфічні грунтові умови росту, а вони, зі свого боку, виступають індикаторами цих умов. Зокрема, Betula ovalifolia Rupr. $є$ оксилофітом і псамофітом, як і Pinus uncinata Ramond ex DC; Microbiota decussata Kom. та Pinus uncinata Ramond ex DC - це петрофіти (літофіти); Betula raddeana Trautv. - кальцефіл.

Висновки та перспективи подальшого дослідження. Отже, проведені дослідження показали, що на території штучних заповідних парків Українського Полісся в складі дендроекзосозофлори переважає група дерев. Аналізуючи їх за класами висоти, очевидно, що переважна кількість досліджених видів належить до дерев першої величини. До групи чагарників входить незначна частка деревних рослин (вісім видів). Результати екологічного аналізу показали переважання морозостійких видів та помірно вимогливих до вологості й родючості грунту дендросозоекзотів.

\section{Джерела та література}

1. Маринич О. М. Фізична географія України / О. М. Маринич, П. Г. Шищенко. - К. : Знання, 2005. -511 с.

2. Маринич О. М. Удосконалена схема фізико-географічного районування України / О. М. Маринич, Г. О. Пархоменко, О. М. Петренко // Український географічний журнал. - 2003. - Т. 41. - С. 16-20.

3. Скавронський П. С. Про трактування поняття «Полісся» та пов'язаних 3 ним термінів у сучасній географічній науці / П. С. Скавронський // Західне Полісся: історія та культура : матеріали наук.-практ. конф., 3-4 груд. 2004 р. : наук. зб. - Вип. І. - Рівне, 2004. - С. 31-39.

4. Серебряков И. Г. Экологическая морфология растений / И. Г. Серебряков. - М. : Высш. шк., 1962. $348 \mathrm{c}$.

5. Калініченко О. А. Декоративна дендрологія / О. А. Калініченко. - К. : Вища шк., 2003. - 200 с.

6. Заповідна дендросозофлора Лісостепу України / НУБіП України ; під ред. С. Ю. Поповича. - К. : ТОВ «Аграр Медіа Груп», 2010. - 262 с.

7. Заповідна дендросозофлора Степу України : монографія / [С. Ю. Попович, А. С. Власенко, Є. І. Берегута та ін.] ; за ред. С. Ю. Поповича. - К. : ЦП «Компринт», 2013. - 260 с.

8. Савоськіна А. М. Сучасний видовий склад дендрофлори парків-пам'яток садово-паркового мистецтва поліської частини Рівненської області / А. М. Савоськіна // Наукові основи підвищення продуктивності та біологічної стійкості лісових та урбанізованих екосистем : матеріали 65-ї наук.-техн. конф.- Львів : РВВ НЛТУ України, 2015. - С. 110-111.

9. Савоськіна А. М. Особливості складу дендросозофітів парків-пам'яток садово-паркового мистецтва Українського Полісся / А. М. Савоськіна // Біоресурси лісових та урбанізованих екосистем: відтворення, збереження і раціональне використання : тези доп. Міжнар. наук.-прак. конф. (23-24 квіт. 2015 р.). К. : «ЦП «Компринт», 2015. - С. 166-167.

Савоськина Анна. Биоморфологическая и экологическая структура экзотической дендросозофлоры заповедных парков Украинского Полесья. В статье приведены результаты анализа биоморфологической и экологической структуры раритетной экзотической дендрофлоры ex situ ботанических садов, дендропарков, парков-памятников садово-паркового искусства и зоопарков Украинского Полесья. Обнаружено, что в составе дендросозофлоры данного региона исследований преобладающей является группа деревьев. Среди небольшого количества раритетных экзотических видов кустарников обнаружены все три группы их высоты. Результаты экологического анализа показали высокую адаптивную способность большинства экзотических раритетных древесных растений к климатическим условиям региона исследований, которое проявляется в преобладании гелиофитов, мезофитов и мезотрофов. Проведение таких исследований важно, ведь, нарушение тех или иных эктопических условий местообитаний древесных растений может привести к сокращению численности их популяций или даже полного исчезновения, особенно в современных условиях сильного антропогенного давления на природную компоненту нашей планеты.

Ключевые слова: Украинское Полесье, заповедные парки, дендросозоэкзоты, структура дендроэкзосозофлоры, биоморфы, экогруппы.

Savoskina Anna. Biomorfological and Ecological Structure of Exotic Dendrosozoflora of Protected Parks of the Ukrainian Polissya. The results of the analysis of biomorfological and ecological structure of exotic rarity dendroflora ex situ botanical gardens, arboretums, parks, monuments of landscape art and zoos Ukrainian Polissya. It 
has been found that the composition of the region dendrosozoflora research is the predominant group of trees. Among the small number of rare exotic species of shrubs are found all three groups of their height. The results of the environmental analysis showed a high adaptive capacity of most exotic rare woody plants to the climatic conditions of the region's research, which is reflected in the prevalence heliophytyc, mesophytyc and mesotrophyc. Such research is important because, breach of certain conditions ecotope habitats woody plants may lead to reduction of their populations and even extinction especially in the current conditions of strong anthropogenic pressure on the natural component of our planet.

Key words: Ukrainian Polissya, conservation parks, dendrosozoekzots, structure of dendroekzosozoflora, biomorphs, ecogroups.

Стаття надійшла до редколегії 06.02.2016 p.

УДК 582.929.4:581.48

\author{
Людмила Кубінська, \\ Олена Мельничук, \\ Алла Гордійчук
}

\title{
Окремі аспекти інтродукції Scutellaria baicalensis Georgi. в умовах Кременецького горбогір'я
}

Установлено особливості росту та розвитку Scutellaria baicalensis Georgi при інтродукції в умовах Кременецького ботанічного саду. Рослини, розмножуючись насіннєвим способом, цвітуть і плодоносять, формують повноцінне насіння, починаючи $з$ першого року життя.

Ключові слова: Scutellaria baicalensis, інтродукція, насіння, схожість, енергія проростання.

Постановка наукової проблеми та ії значення. Повноцінне забезпечення доступними ліками населення України - одна $з$ найгостріших проблем у зв'язку з послабленням імунітету, викликаним несприятливими економічними й екологічними умовами, у тому числі й наслідками Чорнобильської трагедії.

Статистичні дані свідчать про те, що першість серед хвороб населення нашої держави посідають серцево-судинні захворювання. Як показують результати досліджень, цінною сировиною у виготовленні препаратів для лікування цих хвороб є Scutellaria baicalensis Georgi. Зважаючи на велику цінність S. baicalensis як джерела лікарської сировини, пропонуємо ії введення в культуру в господарствах різних форм власності, що може стати надійним засобом отримання достатньої кількості сировини для медичної промисловості. Рослина багата на фармакологічно активні речовини, флавоноїди (байкалин, байкалеїн, вагонин), глікозиди, стероїдні сапоніни, дубильні речовини, ефірну олію, вітаміни, мінеральні речовини та ін. [1].

Препарати шоломниці у вигляді спиртового екстракту виявляють седативні, гіпотензивні й протисудомні властивості. I, що дуже важливо, настоянки, або настої, кореневищ досить ефективні для лікування гіпертонії 1-го та 2-го ступенів, функціональних розладів нервової системи, істеричних станів, серцево-судинних неврозів, безсоння, міокардиту, гострого ревмокардиту суглобового ревматизму, кашлю, коклюшу, бронхіальної астми, запалення легень, глистяної інвазії та дизентирії. За силою заспокійливої дії рослина набагато перевищує валеріану [2].

S. baicalensis - багаторічна рослина з родини губоцвітих (Lamiaceae). Поширена в Східному Сибіру, біля озера Байкал (тому й називається так). Зазвичай росте в степових районах, інколи - на піщаних грунтах. У цьому випадку іiі корені найбільш довгі та розгалужені. Трапляється на щебенистих і кам'янистих схилах, берегах річок, як правило - на відкритих місцях. Рід Scutellaria на території країн СНД нараховує близько 119 видів, в Україні -10 [7].

Мета та завдання дослідження. Мета статті - вивчення біологічних особливостей та етапів онтогенезу S. baicalensis в умовах Кременецького горбогір'я, що дасть можливість в умовах Кре-

(C) Кубінська Л., Мельничук О., Гордійчук А., 2016 